\title{
Correction to: How visual system configuration can play a role in individual recognition: a visual modeling study
}

\author{
Rebecca Trapp ${ }^{1}$ (D) Esteban Fernández-Juricic ${ }^{1}$
}

Published online: 29 October 2021

○) Springer-Verlag GmbH Germany, part of Springer Nature 2021

\section{Correction to: Animal Cognition}

https://doi.org/10.1007/s10071-021-01548-7

In the original publication of the article, the second author name were erroneously published. It is published as "Fernandez-Juricic" (missing the accent) but the correct name should be "Fernández-Juricic". This has been corrected in this paper.

Publisher's Note Springer Nature remains neutral with regard to jurisdictional claims in published maps and institutional affiliations.

The original article can be found online at https://doi.org/10.1007/ s10071-021-01548-7.

Rebecca Trapp

rtrapp@ purdue.edu

1 Department of Biological Sciences, Purdue University,

West Lafayette, IN, USA 